Finanse, Rynki Finansowe, Ubezpieczenia nr 3/2017 (87), cz. 2

DOI: $10.18276 /$ frfu.2017.87/2-17

s. $189-201$

\title{
Wpływ podatku od niektórych instytucji finansowych na wartość rynkową banków komercyjnych w Polsce
}

\author{
Pawel Witkowski*
}

\begin{abstract}
Streszczenie: $\mathrm{Cel}$ - Ocena wpływu wprowadzenia podatku bankowego na wartość rynkową banków komercyjnych w Polsce.

Metodologia badania - W badaniu wykorzystano analizę zdarzeń (event study).

Wynik - Z przeprowadzonych badań wynika, że wprowadzenie podatku bankowego wpłynęło pozytywnie na wartość rynkową przedsiębiorstw, co można tłumaczyć oczekiwaniem inwestorów, że koszt ten zostanie przerzucony z nawiązką na klientów banku.

Oryginalność/wartość - Dotychczasowe badania skupiały się przede wszystkim na analizie treści ustawy o podatku od niektórych instytucji finansowych bądź wpływie wspomnianego podatku na akcję kredytową i ryzyko finansowania (funding risk). Przeprowadzone badanie jest pierwszym, wykorzystującym analizy zdarzeń przy ocenie wprowadzenia podatku bankowego w Polsce na wartość banków, co prawdopodobnie wynika z tego, że w badanym okresie wystąpiło inne bardzo istotne zdarzenie (przedstawienie projektu tzw. ustawy frankowej), którego wpływ jest trudny do wyizolowania. Mimo wspomnianej wady, istotny jest wniosek płynący z badań, gdyż oba zdarzenia powinny, jak przewidywano, negatywnie wpłynąć na wartość rynkową banków.
\end{abstract}

Słowa kluczowe: podatek bankowy, wartość przedsiębiorstwa, analiza zdarzeń

\section{Wprowadzenie}

Wprowadzony ustawą z 15 stycznia 2016 roku o podatku od niektórych instytucji finansowych (Dz.U. 2016 poz. 68) tzw. podatek bankowy nie jest koncepcją nową czy tym bardziej niespotykaną w praktyce formą opodatkowania. Krajami należącymi do UE, które podobnie jak Polska nie wprowadziły podatku bankowego do roku 2016 były tylko Bułgaria, Chorwacja, Czechy, Estonia, Irlandia, Litwa, Luksemburg czy też Malta. Pierwsze projekty ustaw były prezentowane w Polsce już w 2010 roku (druk sejmowy nr 3838), czy też w 2011 roku (druk sejmowy nr 4250). Można zatem powiedzieć, że sam fakt wprowadzenia podatku bankowego nie powinien zaskakiwać czy też budzić większych wątpliwości. Wątpliwości budzą jednak efekty wprowadzenia wspomnianego podatku. Każda z grup interesu ma inne oczekiwania względem podatku bankowego. Inne oczekiwania ma ustawodawca, inne

* Paweł Witkowski, Uniwersytet Szczeciński, Wydział Nauk Ekonomicznych i Zarządzania, e-mail: pawel. witkowski@usz.edu.pl 
właściciele banku, pracownicy banku czy też klienci banku. Częściową odpowiedź na pytanie, czy i jakie oczekiwania ustawa zrealizowała, może przynieść wartość rynkowa banków komercyjnych, a dokładniej zmiana tej wartości w efekcie wprowadzonej ustawy. Celem artykułu jest ocena wpływu wprowadzenia podatku bankowego na wartość rynkową banków komercyjnych, co pośrednio może dać odpowiedź na pytanie, kto poniósł koszt wprowadzonego podatku.

\section{Przeslanki wprowadzenia podatku bankowego}

Dyskusja nad wprowadzeniem podatku bankowego toczy się w państwach Unii Europejskiej od co najmniej kilkudziesięciu lat. Chęć wprowadzenia tego podatku należy łączyć z malejącymi wpływami z tytułu podatku dochodowego od tych instytucji, co wynika z powszechnie stosowanych przez te instytucje praktyk optymalizacji podatkowej. Na drodze do urzeczywistnienia tej koncepcji stanął kryzys ekonomiczny, który przede wszystkim dotknął instytucje finansowe. Państwa w takiej sytuacji nie tylko nie mogły wprowadzić wspomnianego podatku, ale musiały często wspomagać finansowo banki, chroniąc je przed bankructwem (tzw. instytucje ważne systemowo). Ostatecznie kryzys ekonomiczny nadał omawianemu podatkowi dodatkowego znaczenia. Podatek bankowy nie miał już tylko stanowić remedium na optymalizowanie opodatkowania podatku dochodowego przez banki, ale miał być również formą zadośćuczynienia za pomoc sektorowi bankowemu przez poszczególne rządy państw europejskich w okresie kryzysu (Gajewski, 2016a, s. 3). Trochę inaczej cel podatku bankowego postrzega Europejski Bank Centralny (EBC), pomijając kwestię dokonywanej przez banki optymalizacji w ramach podatku dochodowego. Jak podaje EBC - wprowadzenie opodatkowania instytucji finansowych rozważano przede wszystkim z dwóch powodów, w celu zapewnienia zrównoważonego podziału kosztów wynikających z potencjalnych upadłości instytucji finansowych pomiędzy podatników i sektor finansowy (w tym zadośćuczynienie za wcześniejszą pomoc) oraz w celu ograniczania ryzyk kreowanych przez instytucje finansowe (Opinia..., 2016, s. 3) ${ }^{1}$.

Biorąc pod uwagę cel regulacji, zwłaszcza ,zapewnienie zrównoważonego podziału kosztów wynikających z potencjalnych upadłości instytucji finansowych pomiędzy podatników i sektor finansowy", krytyczne znaczenie ma ograniczenie zdolności przerzucania tych kosztów na konsumentów oraz ograniczenie możliwości unikania opodatkowania. Jeżeli nie

1 Warto wspomnieć, że podatek bankowy był tylko jedną z propozycji osiągnięcia wspomnianych przez EBC celów. W swojej rekomendacji dla krajów G-20, Międzynarodowy Fundusz Walutowy (MFW) wymienił trzy możliwe narzędzia, które mogłyby pomóc w realizacji wspomnianych celów, a mianowicie opłata na fundusz stabilizacyjny (Financial Stability Contribution) na równi z podatkiem bankowym (Bank tax, Bank levy), podatek od aktywności finansowej (Financial Activities Tax) oraz podatek od transakcji finansowych (Financial Transactions Tax), czyli tzw. podatek Tobina (International Monetary Fund, 2010). Najwięcej miejsca MFW poświęcił podatkowi bankowemu. W niektórych krajach podatek Tobina, opłata na fundusz stabilizacyjny, czy podatek od aktywności finansowej, nie są alternatywami dla podatku bankowego. Dla przykładu we Francji i Wlk. Brytanii jednoczenie funkcjonuje podatek od transakcji finansowych i podatek bankowy, natomiast w Polsce funkcjonuje jednocześnie opłata na fundusz stabilizacyjny i podatek bankowy. 
zabezpieczono tego ryzyka i banki przerzuciły koszt na klientów, to można uznać, że ustawa nie spełniła pierwotnych celów. W konsekwencji koszt ratowania instytucji finansowych poniósł wyłącznie podatnik. Ponadto nie skorygowano błędnie funkcjonującego mechanizmu i system finansowy nadal ma znaczącą skazę.

Należy także wspomnieć, że w uzasadnieniu do projektu ustawy jedynymi wymienionymi celami są - pozyskanie dodatkowego źródła finansowania wydatków budżetowych, w szczególności wydatków społecznych, oraz zwiększenie udziału sektora finansowego w finansowaniu wydatków budżetowych (Poselski projekt..., 2015). Akcentuje się, że przerzucanie nie powinno wystąpić, gdyż jest to podatek bezpośredni, aczkolwiek ostatecznie zauważa się, że przerzucanie może wystąpić wstecz (większa presja na obniżenie wynagrodzeń lub cen usług nabywanych) oraz w przód w przypadku kredytów (zarówno korporacyjnych, jak i indywidualnych). Jako czynniki ograniczające wspomniane zjawisko wymienia się: istniejącą konkurencję na rynku, aktywne działania UOKIK oraz istniejące i proponowane w projekcie (art. 16) rozwiązania prawne.

Niektórzy ekonomiści uważali jednak, że teza mocnej konkurencji w sektorze bankowym jest nieco na wyrost i istnieje poważna obawa, że podatek bankowy zostanie przerzucony na klientów banku, a nawet, że koszty te zostały częściowo przerzucone jeszcze przed zakończeniem procesu legislacyjnego przez podwyższenie opłat i prowizji (Zubert, 2016, s. 10). Obawy te podzielali także niektórzy doradcy podatkowi (Malinowski, 2016, s. 4).

\section{Analiza prawno-ekonomiczna ustawy o podatku od niektórych instytucji finansowych}

Przez ostatnie lata wypracowano kilka koncepcji podatku bankowego, przy czym można je podzielić na dwie podstawowe grupy - na opodatkowanie pasywów i opodatkowanie aktywów banku. W ramach danej grupy, poszczególne wersje różnią się między sobą przede wszystkim wyłączeniami. Od tego ogólnego podziału występują wyjątki, na przykład w Danii opodatkowuje się fundusz wynagrodzeń, natomiast w Niemczech i Portugali banki płacą dodatkowo podatek od instrumentów pochodnych poza sumą bilansową. W przeważającej części krajów, w których wprowadzono opodatkowanie instytucji finansowych, zdecydowano się na opodatkowanie pasywów. Dziwić może zatem fakt, że w Polsce zdecydowano się na opodatkowanie aktywów. W opinii Europejskiego Banku Centralnego już sama podstawa opodatkowania opisana w art. 3 Ustawy z 15 stycznia 2016 roku o podatku od niektórych instytucji finansowych (Dz.U. 2016, poz. 68), czyli aktywa bez uwzględnienia ich ryzyka, może przyczynić się do przerzucania kosztów podatku na konsumentów oraz zmniejszenia dostępności kredytów. Wstępne badania potwierdzały taką możliwość (Borowski, Jaworski, Tymoczko, 2016) $)^{2}$. Paradoksalnie tak określona podstawa opodatkowania może zachęcić instytucje finansowe do bardziej ryzykownych produktów czy wykorzystania operacji pozabilansowych. Istnieje także ryzyko sztucznego przerzucania portfela kredytowego po-

2 Niektórzy naukowcy wątpili jednak, że tak się stanie (Modzelewski, 2015). 
między oddziałami lub spółkami powiązanymi banku, zwłaszcza do krajów, gdzie podatek bankowy nie jest stosowany, stawka jest niższa lub podstawa opodatkowania nie uwzględnia przerzucanych aktywów.

Ryzyko unikania opodatkowania niesie także wybór źródła oraz momentu pozyskania informacji odnośnie do podstawy opodatkowania (Gajewski, 2016b, s. 6-9). Zgodnie z art. 5 ust. 1 wspomnianej ustawy, źródłem informacji przy ustalaniu podstawy opodatkowania jest zestawienie obrotów i sald na ostatni dzień miesiąca na kontach księgi głównej. Kwota ta nie jest potwierdzana przez biegłego rewidenta, a samo wyznaczanie sumy aktywów na konkretny dzień stwarza możliwość manipulacji. Banki mogą na przykład wykorzystać możliwość odliczenia od podstawy opodatkowania wartość posiadanych skarbowych papierów wartościowych (art. 5 ust. 9 omawianej ustawy), zakupić je w dniu ustalania sumy aktywów, a następnego dnia sprzedać. Stanowczo lepszym rozwiązaniem byłoby opodatkowanie roczne na podstawie zatwierdzonego sprawozdania, z miesięcznymi zaliczkami, na podstawie średnich wielkości aktywów w miesiącu.

Inną formą unikania opodatkowania może być przewidziany w art. 11 ust. 2 pkt 1 zwolnienie w przypadku wdrożenia programu naprawczego. Prawo bankowe nakazuje opracowanie i realizację programu naprawczego w przypadku powstania straty bilansowej lub nawet groźby jej wystąpienia, co może być nadużywane (Gajewski, 2016c, s. 101).

Wybór kwoty progu zwolnienia na poziomie 4 mld zł dla banków, 2 mld zł dla zakładów ubezpieczeń oraz $200 \mathrm{mln}$ dla instytucji pożyczkowych oznacza, że podatkiem objęte są tylko największe instytucje. $Z$ jednej strony może to ograniczyć efekt przerzucania kosztów, gdyż nie wszystkie jednostki zostały objęte tym podatkiem (zwiększenie konkurencyjności mniejszych instytucji). Z drugiej strony duże jednostki - z racji swojej pozycji na rynku mają większą możliwość przerzucania kosztów. Istotne znaczenie ma tu koncentracja rynku. Im większa koncentracja, tym zdolność do przerzucania kosztów jest większa (Kogler, 2016). Istnieje także obawa, że małe banki podążą za dużymi bankami (objętymi podatkami) i podwyższą oprocentowanie kredytów lub/i obniżą oprocentowanie depozytów, poprawiając swoją rentowność (Mironczuk, 2016, s. 37).

Z przeprowadzonych analiz prawnych i ekonomicznych Ustawy z 15 stycznia 2016 roku o podatku od niektórych instytucji finansowych (Dz.U. 2016, poz. 68) wynika, że w obecnej postaci ustawa ma wiele luk i istnieje duże ryzyko przerzucania kosztów podatku na konsumentów czy też unikania opodatkowania (Opinia..., 2016, s. 2-3). Problem ten nie dotyczy jednak tylko Polski, gdyż przerzucanie podatków na klientów w sektorze bankowym - z racji specyfiki tego sektora - w mniejszym bądź większym stopniu występuje w każdym kraju (Buch, Hilberg, Tonzer, 2013). Z całą pewnością zjawisko to jednak można ograniczać, a treść ustawy budzi wiele wątpliwości. 


\section{Wykorzystanie analizy zdarzeń do oceny wpływu wprowadzenia podatku bankowego na wartość rynkową przedsiębiorstw}

Analiza zdarzeń (event study) jest metodą statystyczną pozwalającą ocenić czy dane zdarzenie miało istotny wpływ na cenę rynkową akcji, a także pozwala oszacować wielkość i kierunek tego wpływu. Jednym z podstawowych założeń analizy zdarzeń jest założenie efektywności informacyjnej rynku. Jednocześnie za pomocą tej metody ocenia się czy efektywność informacyjna występuje na rynku (w tym, w jakiej postaci), a każde badanie wykazujące istotność badanego zdarzenia staje się dowodem na efektywność informacyjną rynku.

Kluczowym etapem podczas przeprowadzania analizy zdarzeń jest wyznaczenie okna zdarzenia. W przypadku podatku bankowego byłoby rozsądne wyznaczenie okna zdarzenia na podstawie daty zakończenia procesu legislacyjnego, czyli podpisania ustawy przez prezydenta. Okno zdarzenia zwykło ustalać się wykraczając poza dzień zdarzenia. Za takim zabiegiem przemawiają dwa powody. Rozciągnięcie o okresy przed zdarzeniem argumentuje się możliwością pojawienia się informacji odnośnie do danego zdarzenia wcześniej (w tym także zakłada się możliwość wycieku informacji - założenie silnej efektywności informacyjnej rynku). Wydłużenie okresu o kolejne dni argumentuje się koniecznością przeanalizowania informacji przez inwestorów (osiągnięcie konsensus rynkowego). W przypadku podatku bankowego, wyznaczenie okna zdarzenia jest szczególnie trudne. Pierwsze projekty podatku bankowego były rozpatrywane już w 2010 i 2011 roku. Wyznaczenie okna od tego okresu oczywiście nie ma sensu, gdyż ustawa nie została wprowadzona, ponadto minęło dużo czasu i doszło do wielu innych istotnych zdarzeń w danym okresie (osobliwością są badania, w których okno zdarzenia jest dłuższe niż jeden rok), cena rynkowa z całą pewnością „oczyściła się" z wpływu wspomnianych projektów. Wyznaczenie początku okna zdarzenia od momentu tuż przed wyborami parlamentarnymi (25.10.2015 r.) wydaje się także uzasadnione, gdyż podatek bankowy był jednym ze sztandarowych haseł partii, która następnie zdobyła bezwzględną większość parlamentarną. Powodem przeciw takiemu wyborowi jest to, że od tego czasu doszło do wielu zdarzeń, w tym związanych bezpośrednio z bankami komercyjnymi, na przykład zawieszenie działalności SK Banku (SK Bank, 2015), podwyższenie stawki opłaty ostrożnościowej BFG pod koniec listopada 2015 roku (BFG, 2015), czy wejście w życie Ustawy z 9 października 2015 roku o wsparciu kredytobiorców znajdujących się w trudnej sytuacji finansowej, którzy zaciągnęli kredyt mieszkaniowy (Dz.U. 2015, poz. 1925). Dodatkowo podatek bankowy był tylko jedną z propozycji. Z racji, że projekt trafił do sejmu 3 grudnia 2015 roku, rozsądne wydaje się wyznaczenie okna zdarzenia od tej daty. Ostatecznie zdecydowano się na wyznaczenie okna zdarzenia w konwencji $(-30,30)$, czyli 30 dni sesyjnych przed i po zdarzeniu. Okno zdarzenia rozpoczyna się 27 listopada 2015 roku, a kończy 26 lutego 2016 roku. Wyznaczenie tak długiego okresu po zdarzeniu wynika z tego, że nie było pewności jak Ministerstwo Finansów będzie reagować na ewentualne przerzucanie kosztów czy próby uniknięcia opodatkowania. W przypadku braku ceny rynkowej akcji w wyznaczonym dniu, do analizy wykorzystywano cenę z dnia następnego/poprzedniego. Należy także zauważyć, że przeprowadzone badanie ma wadę. W dniu zdarzenia doszło do 
innego, bardzo istotne dla badanej grupy podmiotów zdarzenia, a mianowicie przedstawiona została prezydencka propozycja ustawy o sposobach przywrócenia równości stron, czyli tzw. ustawa frankowa. Wątek ten zostanie poruszony w dalszej części artykułu.

Kolejnym etapem jest wyliczenie dodatkowych stóp zwrotów $\left(A R_{i i}\right)$. Aby obliczyć dodatkowe stopy zwrotu dla okna zdarzenia, od ceny rynkowej odejmuje się - oszacowane na podstawie wybranego modelu - oczekiwane stopy zwrotu dla danej akcji. Współczynniki wspomnianego modelu estymuje się na podstawie danych sprzed okna zdarzenia (okno estymacji).

$$
A R_{i t}=R_{i t}-E\left(R_{i t}\right)
$$

gdzie:

$A R_{i t}$ - dodatkowa stopa zwrotu osiągnięta z $i$-tej akcji w okresie $t$, $R_{i t}$ - rzeczywista stopa zwrotu osiągnięta z $i$-tej akcji w okresie $t$, $E\left(R_{i t}\right)$ - oczekiwana stopa zwrotu $\mathrm{z} i$-tej akcji w okresie $t$ w sytuacji, gdyby zdarzenie nie wystąpiło, $t$ - dzień lub miesiąc w zależności od przyjętych do obliczeń danych i jednostki „okna zdarzenia".

W teorii zakłada się, że znany jest model, który dokładnie szacuje stopę zwrotu z danego instrumentu („normalną” stopę zwrotu, czyli stopę pozbawioną wpływu badanych zdarzeń). W praktyce stosuje się modele, które tylko po części tłumaczą zachowanie ceny rynkowej akcji (np. model rynkowy, GARCH, modele wieloczynnikowe, model trzyczynnikowy Fammy i Frencha), wychodząc z przekonania, że zbyt wiele czynników wpływa na cenę rynkową spółki. Eliminuje się tylko najważniejsze czynniki (np. rynkowe, gdyż drastyczne zmiany na rynku, jak kryzys finansowy, mogłyby rzutować na wyniki). W badaniu wykorzystano model rynkowy (tzw. model Sharpa), ponieważ jest on najczęściej stosowanym i ogólnie akceptowanym modelem. Model jest szacowany na podstawie danych z tzw. okna estymacji. Wyznaczenie zbyt długiego okna estymacji może wiązać się z uwzględnieniem wpływu czynników, które nie mają już znaczenia. Zbyt krótkie wyznaczenie okna estymacji skutkuje małą liczbą obserwacji, co sprawia, że wyniki estymacji są wątpliwe. Z drugiej strony za duża liczba obserwacji wiąże się z problemem dużego szumu losowego. Uznano, że przy założeniu dziennych stóp zwrotu i oknie zdarzenia liczącym 60 dni sesyjnych, okno estymacji liczące 250 dni sesyjnych stanowi dobry kompromis. Okno zdarzenia oraz okno estymacji zaprezentowano na osi czasu na rysunku 1 . 


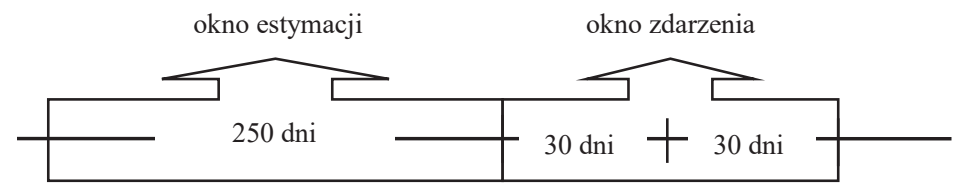

$17.02 .2015 \quad 15.01 .2016 \quad 14.02 .2016$

Rysunek 1. Przyjęte okno estymacji oraz okno zdarzenia przedstawione na osi czasu Źródło: opracowanie własne.

Kolejnym etapem jest wyliczenie średnich dodatkowych stóp zwrotu dla poszczególnych okresów okna zdarzenia $(A A R)$, skumulowanych dodatkowych stóp zwrotu z całego okna zdarzenia dla poszczególnych spółek $\left(C A R_{i}\right)$, skumulowanej średniej dodatkowej stopy zwrotu z okna zdarzenia (CAAR) oraz ocena ich istotności. Sposoby obliczania wspomnianych charakterystyk prezentują poniższe wzory.

$$
A A R_{t}=\frac{\sum_{i=1}^{N} A R_{i t}}{N}
$$

gdzie:

$A A R_{t}$ - średnia dodatkowych stóp zwrotu wszystkich badanych akcji w okresie $t$ (average abnormal returns),

$N$ - liczba badanych spółek w „oknie zdarzenia”, $A R_{i t}$ - oznaczenia jak wcześniej.

$$
C A R_{i}=\sum_{t_{1}}^{t_{2}} A R_{i t}
$$

gdzie:

$C A R_{i}$ - skumulowana dodatkowa stopa zwrotu osiągnięta z i-tej akcji w oknie zdarzenia, $t_{1}$ - początek ,okna obserwacji”,

$t_{2}$ - koniec „okna obserwacji”,

$A R_{i t}$ - oznaczenia jak wcześniej.

$$
C A A R=\frac{\sum_{i=1}^{N} C A R_{i}}{N}=\sum_{t_{1}}^{t_{2}} A A R_{t},
$$

gdzie:

CAAR - skumulowana średnia dodatkowa stopa zwrotu w „oknie obserwacji” (cumulative average abnormal returns), $t_{1}, t_{2}, C A R_{i}, A A R_{t}$ - oznaczenia jak wcześniej.

Skumulowane dodatkowe stopy zwrotu $\left(C A R_{i}\right)$ oraz skumulowaną średnią dodatkową stopę zwrotu (CAAR) dla badanego okna zdarzenia przedstawiono w tabeli 1. Badaniu poddano 16 banków komercyjnych notowanych na Giełdzie Papierów Wartościowych 
w Warszawie. Z przeprowadzonego badania wynika, że wprowadzenie podatku bankowego nie tylko miało istotny wpływ na wartość rynkową banków komercyjnych, ale wpływ ten miał w większości pozytywny charakter.

\section{Tabela 1}

Skumulowana dodatkowa stopa zwrotu poszczególnych banków

\begin{tabular}{llc}
\hline Lp & Bank & CAR $_{\mathrm{i}}$ \\
\hline 1. & Alior Bank SA & $-0,114$ \\
\hline 2. & Bank BGŻ BNP Paribas SA & 0,085 \\
\hline 3. & Bank Handlowy w Warszawie SA & $0,3107^{* * *}$ \\
\hline 4. & Bank Ochrony Środowiska SA & $-0,1331$ \\
\hline 5. & Bank Zachodni WBK SA & $0,1755^{*}$ \\
\hline 6. & Getin Noble Bank SA & $0,4018^{*}$ \\
\hline 7. & Getin Holding SA & $0,2543^{*}$ \\
\hline 8. & Idea Bank SA & $-0,0364$ \\
\hline 9. & ING Bank Śląski SA & 0,1086 \\
\hline 10. & mBank SA & $0,2162^{*}$ \\
\hline 11. & Bank Millennium SA & $0,2745^{*}$ \\
\hline 12. & Bank Pekao SA & 0,1689 \\
\hline 13. & Powszechna Kasa Oszczędności Bank Polski SA & 0,0457 \\
\hline 14. & Banco Santander SA & $-0,0601$ \\
\hline 15. & UniCredit SpA & $-0,366^{* *}$ \\
\hline 16. & Bank BPH SA & 0,0825 \\
\hline CAAR & $0,0889^{*}$ \\
\hline
\end{tabular}

Oznaczenia: $* * *$ - poziom istotności $0,01, * *$ - poziom istotności $0,05, *$ - poziom istotności 0,1 .

Źródło: opracowanie własne.

Analiza kształtowania się skumulowanej średniej dodatkowej stopy zwrotu (CAAR) oraz średnich dodatkowych stóp zwrotu $\left(A A R_{t}\right)$ potwierdza istotny wpływ procesu legislacyjnego podatku bankowego na cenę rynkową banków komercyjnych (rys. 2), a tym samym zasadność tak długiego okna zdarzenia. 


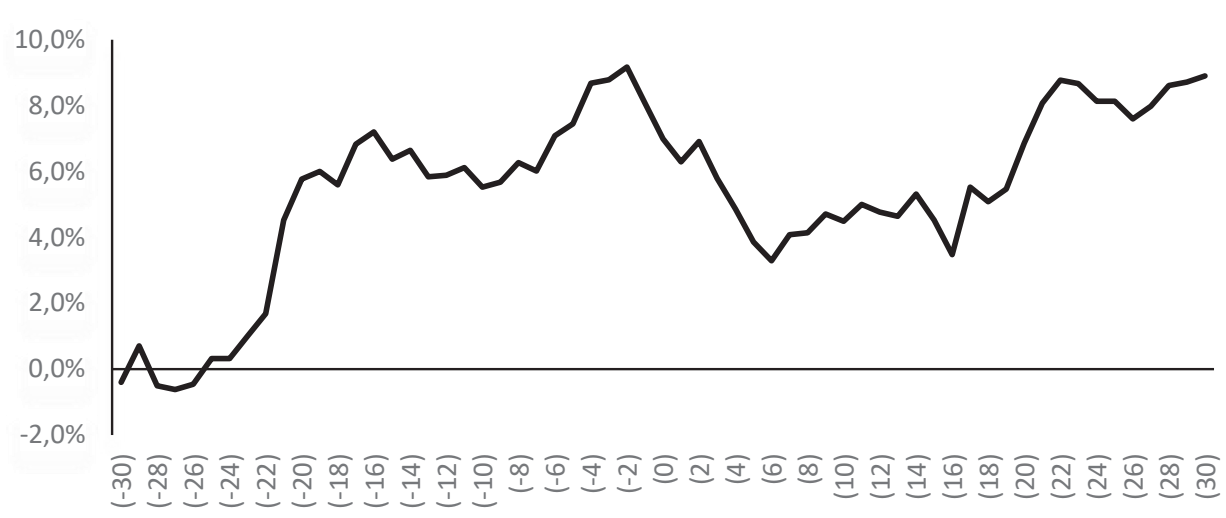

Rysunek 2. Kształtowanie się skumulowanej średniej dodatkowej stopy zwrotu (CAAR) w okresie 30 dni przed i po zdarzeniu

Źródło: opracowanie własne.

Średnie dodatkowe stopy zwrotu ${ }^{3}$ dla okresów (-29) i (-28), to stopy zwrotu tuż przed 3 grudnia 2015 roku, kiedy wpłynął projekt ${ }^{4}$. Okresy (-21) oraz (-20) odpowiadają dwóm, ewentualnie trzem dniom po dacie skierowania do pierwszego czytania (8.12.2015 r.). Okres (-17) przypada na jeden, ewentualnie dwa dni przed pierwszym czytaniem (17.12.2015 r.), natomiast okres (-13) dniu sprawozdania komisji (22.12.2015 r.). Uwagę zwracają średnie dodatkowe stopy zwrotu w oknie $(-1,6)$, gdyż są one ujemne ${ }^{5}$. Mając na uwadze przeciętne dodatkowe stopy zwrotu z okresów wcześniejszych, należy stwierdzić, że jest to wynik prawdopodobnie spekulacji, albo ogłoszenia projektu tzw. ustawy frankowej. Świadczy o tym chociaż niesymetryczny, względem dnia zdarzenia, rozkład liczby okresów spadkowych. Spadki zaczęły się jedną sesje przed podpisaniem ustawy przez prezydenta, a skończyły dopiero po sześciu dniach sesyjnych. Ustawa nie uległa dużym zmianom w tym okresie, a jej treść była przedstawiona już 3 grudnia 2015 roku. Ogłoszenie wspomnianego projektu jest z całą pewnością mankamentem przeprowadzonego badania, aczkolwiek należy zauważyć, że po sześciu dniach sesyjnych od podpisania ustawy przez prezydenta, średnia skumulowana dodatkowa stopa zwrotu ponownie zaczęła rosnąć.

Ewentualnym powodem, innym niż brak szczelności ustawy czy też możliwość przerzucenia kosztów na klientów, jest delikatniejszy charakter ustawy frankowej. Skracając jednak okno zdarzenia do postaci (25,0), gdzie datą zdarzenia jest 13 stycznia 2016 roku, stosunek pozytywnych $C A R_{i}$ do negatywnych wyniósł 13:3, a średnia skumulowana dodatkowa stopa zwrotu wyniosła 0,0967\% przy istotności na poziomie 0,02 (tab. 2).

3 Na zamieszczonym wykresie AARt dla kolejnych okresów stanowi zmianę w wielkości CAAR, np. $A A R_{-27}=C A A R_{-30}^{-27}-C A A R_{-30}^{-28}$.

4 Daty zdarzeń związanych z przebiegiem procesu legislacyjnego zaczerpnięto ze strony sejmu RP; http://www. sejm.gov.pl (zakładka „Prace sejmu”).

5 W przeciwieństwie do wszystkich wcześniej wspomnianych, żadna z tych średnich dodatkowych stóp zwrotu nie okazała się istotna statystycznie. 


\section{Tabela 2}

Skumulowana dodatkowa stopa zwrotu poszczególnych banków dla okna zdarzenia zaczynającego się 25 dni sesyjnych przed 13.01.2016 r. i kończącego się w tym dniu

\begin{tabular}{lll}
\hline Lp & Bank & CAR $_{\mathrm{i}}$ \\
\hline 1. & Alior Bank SA & $-0,0778$ \\
\hline 2. & Bank BGŻ BNP Paribas SA & 0,0253 \\
\hline 3. & Bank Handlowy w Warszawie SA & $0,1821^{* *}$ \\
\hline 4. & Bank Ochrony Środowiska SA & $-0,0857$ \\
\hline 5. & Bank Zachodni WBK SA & $0,1435^{* *}$ \\
\hline 6. & Getin Noble Bank SA & $0,4499^{* * *}$ \\
\hline 7. & Getin Holding SA & $0,2919^{* *}$ \\
\hline 8. & Idea Bank SA & 0,0175 \\
\hline 9. & ING Bank Śląski SA & 0,0976 \\
\hline 10. & mBank SA & $0,1645^{* *}$ \\
\hline 11. & Bank Millennium SA & $0,1586^{*}$ \\
\hline 12. & Bank Pekao SA & $0,0865^{*}$ \\
\hline 13. & Powszechna Kasa Oszczędności Bank Polski SA & 0,0283 \\
\hline 14. & Banco Santander SA & 0,0261 \\
\hline 15. & UniCredit SpA & $-0,0574$ \\
\hline 16. & Bank BPH SA & 0,0728 \\
\hline CAAR & & $0,0967^{* * *}$ \\
\hline
\end{tabular}

Oznaczenia: $* * *$ - poziom istotności $0,02, * *$ - poziom istotności $0,05, *$ - poziom istotności 0,1 .

Źródło: opracowanie własne.

Za takim wyznaczeniem okna zdarzenia przemawia fakt, że data prezentacji prezydenckiego projektu nie była znana. Można zatem oczekiwać, że wynik jest wolny od wspomnianego zdarzenia lub wpływ, przy tak wyznaczonym oknie zdarzenia, jest znacznie ograniczony. Dodatkowo inwestorzy mieli dużo czasu na zapoznanie się z projektem podatku bankowego, mimo pojawiających się poprawek. Dla wspomnianego okna zdarzenia, tylko dodatnie skumulowane dodatkowe stopy zwrotu poszczególnych banków okazały się istotne statystycznie. Mimo że przeprowadzenie analizy dla okna zdarzenia w konwencji $(-25,0)$ i datą zdarzenia 13 stycznia 2016 roku jest mocno uzasadnione, a wyniki znacznie bardziej jednoznaczne i istotne statystycznie, to jednak zdecydowano się zaprezentować i omówić dokładnie wyniki dla konwencji $(-30,30)$ i datą centralną 15 stycznia 2016 roku. Z jednej strony jest to spowodowane spostrzeżeniem, że dopiero podpis prezydenta zakończył proces legislacyjny. Z drugiej strony wyniki dla konwencji $(-30,30)$ i dacie centralnej 15 stycznia 2016 roku dają możliwość szerszego przeanalizowania omawianego zdarzenia, jak również przyjrzenia się samej analizie. 


\section{Uwagi końcowe}

Z przeprowadzonych analiz wynika istotna obawa, że banki przerzuciły obciążenia wynikające z Ustawy z 15 stycznia 2016 roku o podatku od niektórych instytucji finansowych (Dz.U. 2016, poz. 68) na klientów. Co istotne, z przeprowadzonego, z wykorzystaniem analizy zdarzeń, badania wynika, że banki przerzuciły wspomniane obciążenia prawdopodobnie z nadwyżką. Trudno zatem oczekiwać pogorszenia rentowności banków, którą przewidywali niektórzy naukowcy (Siudek, 2011). Należy zauważyć, że badanie obarczone jest, z punktu widzenia metodyki analizy zdarzeń, wadą, w postaci wystąpienia innego zdarzenia (prezentacja prezydenckiego projektu ustawy o sposobach przywrócenia równości stron niektórych umów kredytu i zmianie niektórych innych ustaw), nie zmienia to jednak faktu, że oba te zdarzenia powinny negatywnie wpłynąć na cenę rynkową badanych banków komercyjnych (biorąc pod uwagę cel ich wprowadzenia), do czego w większości przypadków nie doszło. Wnioski te potwierdzają wyniki dla okna w konwencji $(25,0)$ i dacie zdarzenia 13 stycznia 2016 roku. Dodatkowo wnioski te potwierdza analiza czynników kształtujących wynik finansowy sektora bankowego. Wynik z tytułu opłat i prowizji dla całego sektora co prawda nieznacznie spadł w 2016 roku (o ok. 703 mln zł), aczkolwiek wynik z tytułu odsetek znacznie wzrósł (2 mld $720 \mathrm{mln}$ zł). Wydaje się zatem, że przerzucenie wspomnianych „kosztów” odbyło się przede wszystkim przez zwiększenie różnicy pomiędzy oprocentowaniem kredytów i depozytów. Jak podaje NBP, dość mocne obniżenie kosztów z tytułu odsetek, to element polityki cenowej banków w reakcji na zmiany prawne i inne wydarzenia w otoczeniu makroekonomicznym banków, polegające na obniżeniu oprocentowania depozytów. Średnioważone oprocentowanie terminowych depozytów złotowych nowych umów spadło z 1,8\% w grudniu 2015 roku, do 1,5\% w czerwcu 2016 roku (NBP, marzec 2017, s. 25). Wzrost oprocentowania kredytów jest szczególnie widoczny w przypadku długoterminowych kredytów mieszkaniowych i pożyczek dla przedsiębiorstw niefinansowych (Fraczyk, 2017, s. 43). Oprocentowanie kredytu hipotecznego wzrosło z 3,44\% w listopadzie 2015 roku, do 3,76\% w lutym 2016 roku, a średnia marża wzrosła z 1,72\% w listopadzie 2015 roku, do 2,04\% w lutym 2016 roku (Raport Amron-Sarfin, 2016, s. 12). Ostatecznie należy zauważyć, że w roku 2016 z planowanych 5,5 mld zł wpływu z podatku bankowego uzyskano kwotę trochę ponad 3 mld zł (Fraczyk, 2017, s. 43). Dalsze badania z całą pewności są potrzebne. Kolejne badanie mogłoby polegać np. na analizie zdarzeń opartej na wolumenie.

\section{Literatura}

BFG (2015), Uchwała nr 26/2015 - wysokość stawki opłaty ostrożnościowej na 2016 rok-banki. Pobrane z: https:// www.bfg.pl/wp-content/uploads/2016/10/uchwala_rady_bfg_nr_26_2015_-_wysokosc_stawki_ostroznosciowej_na__rok_2016____banki.pdf.

Borowski, J., Jaworski, K., Tymoczko, D. (2016). Wpływ podatku bankowego w Polsce na kredyt dla sektora niefinansowego. Studia Ekonomiczne. Zeszyty Naukowe Uniwersytetu Ekonomicznego w Katowicach, 287.

Buch, C.M., Hilberg, B., Tonzer, L. (2013). Taxing Banks: An Evaluation of the Germany Bank Levy, CESifo Working Paper No. 4704. Munich. Pobrane z: https://www.econstor.eu/handle/10419/96873. 
Capelle-Blancard, G., Havrylchyk, O. (2013). The Ability of Banks to Shift Corporate Income Taxes to Customers. CEPII, Working Paper No. 2013-09. Paris. Pobrane z: www.cepii.fr/pdf_pub/wp/2013/wp2013-09.pdf.

Fraczyk, J. (2017). Nie spełnił oczekiwań rządu, ale napędził popyt na obligacje. Bank, 3 (286), 42-43.

Gajewski, D.J. (2016a). Podatek bankowy a zjawisko unikania opodatkowania. Przeglad Ustawodawstwa Gospodarczego, 6 (816).

Gajewski, D.J. (2016b). Podatek bankowy w Polsce - wady i zalety. Analizy i Studia CASP, 1 (1), 1-24.

Gajewski, D.J. (2016c). Podatkowa ucieczka do przodu. Gazeta Bankowa, 6 (1182), 99-103.

International Monetary Fund (16.04.2010). A fair and substantial contribution by the financial sector. Final report for G-20. Pobrane z: https://www.imf.org/external/np/g20/pdf/062710b.pdf.

Kogler, M. (2016). On the Incidence of Bank Levies: Theory and Evidence, nr 1606, Economic Working Paper Series, Uniwersity of St. Gallen, Schoolof Economics and Political Science. Pobrane z: http://econpapers. repec.org/paper/usgeconwp/2016_3a06.htm.

Malinowski, D.M. (2016). Podatek bankowy - podstawowe założenia, instytucje i skutki jego wprowadzenia. Przeglad Podatkowy, 2 (298), 3-4.

Mironczuk, T. (2016). Podatek bankowy - wstęp do przebudowy rynku finansowego. Nowoczesny Bank Spótdzielczy, 3, 36-39.

Modzelewski, W. Podatek bankowy, ale jaki? Pobrane z: http://www.polskieradio.pl/42/4393/Artykul/1473386,Podatek-bankowy-ale-jaki.

Narodowy Bank Polski (marzec 2017). Porównanie wysokości prowizji i opłat związanych z rozliczeniami pieniężnymi w złotych w polskim sektorze bankowym w okresie czerwiec $2016 r$. - grudzień $2016 r$. Pobrane z: https:// www.nbp.pl/home.aspx?f=/systemplatniczy/prowizje_i_oplaty/index.html.

Narodowy Bank Polski (lipiec 2016). Syntetyczna informacja na temat wpływu podatku od niektórych instytucji finansowych na sytuację banków komercyjnych. Pobrane z: https://www.knf.gov.pl/opracowania/sektor_bankowy/raporty_i_opracowania/analizy_opracowania/.

Opinia Europejskiego Banku Centralnego z dnia 12 stycznia 2016 r. o podatku od niektórych instytucji finansowych (CON/2016/1). Pobrane z: https://www.ecb.europa.eu/ecb/legal/pdf/pl_con_2016_1_f_sign.pdf.

Poselski projekt ustawy o podatku od niektórych instytucji finansowych (2015). Druk 75, Pobrane z: http://www. sejm.gov.pl/sejm8.nsf/druk.xsp?nr=75.

Raport Amron-Safrin (maj 2016). Ogólnopolski raport o kredytach mieszkaniowych i cenach transakcyjnych, Raport nr 27. Pobrane z: http://www.amron.pl/strona.php?tytul=raporty-amron-sarfin.

Siudek, T. (2011). Podatek bankowy - konsekwencje dla sektora bankowego w Polsce. Zeszyty Naukowe SGGW. Ekonomika i Organizacja Gospodarki Żywnościowej, 92, 63-76.

SK Bank (2015). Zawieszenie działalności Spółdzielczego Banku Rzemiosła i Rolnictwa w Wołominie oraz wystapienie z wnioskiem o ogloszenie upadtości banku. Pobrane z: https://www.skbank.pl/UploadedFiles/files/ Komunikat\%2520KNF\%2520o\%2520zawieszeniu.pdf.

Ustawa z dnia 26 lipca 2013 r. o zmianie ustawy o Bankowym Funduszu Gwarancyjnym oraz niektórych innych ustaw, Dz.U. z 2013 r., poz. 1012.

Ustawa z dnia 9 października 2015 r. o wsparciu kredytobiorców znajdujących się w trudnej sytuacji finansowej, którzy zaciągnęli kredyt mieszkaniowy, Dz.U. 2015, poz. 1925.

Ustawa z dnia 15 stycznia 2016 roku o podatku od niektórych instytucji finansowych, Dz.U. 2016, poz. 68.

Zubert, M. (2016). Podatek bankowy wszedł w życie. Homme \& Market, 2.02.2016, 10. 


\title{
THE IMPACT OF BANK TAX ON MARKET VALUE OF COMMERCIAL BANKS IN POLAND
}

\begin{abstract}
Purpose - investigate the impact of introducing bank tax on the market value of commercial banks in Poland as well as tax assessment from the point of view of the prerequisites for introduction.

Design/Methodology/approach - an event study methodology was used to empirically examine stock market reaction to the introduction of bank tax in Poland.

Findings - The stock market reacted positively to the introduction of bank tax. This is probably due to the fact that investors are convinced that banks will be able to pass on costs to customers.

Originality/value - The use of event analysis in assessing the introduction of a banking tax in Poland is probably the first one, which is likely due to the fact that another very important event occurred in the period under consideration whose impact is difficult to isolate. Despite the aforementioned drawback the research conclusion is significant because both of these events should have a negative impact on the market value of the banks while the study results showing something quite the opposite.
\end{abstract}

Keywords: Bank tax, Bank Levy, corporate value, event study

\section{Cytowanie}

Witkowski, P. (2017). Wpływ podatku od niektórych instytucji finansowych na wartość rynkową banków komercyjnych w Polsce. Finanse, Rynki Finansowe, Ubezpieczenia, 3 (87/2), 189-201. DOI: 10.18276/frfu.2017.87/2-17. 